\title{
圧縮ブレースを用いて耐震補強する既存 $\mathrm{RC}$ 造ピロティ架構の 耐震性能の評価 \\ PREDICTION OF THE SEISMIC PERFORMANCE OF EXISTING PILOTI-TYPE R/C FRAMES STRENGTHENED USING COMPRESSIVE BRACINGS FOR SEISMIC RETROFIT
}

\author{
塩屋晋一*, 大川光雄 ${ }^{* *}$, 岡元夕弥*** \\ Shinichi SHIOYA, Mitsuo OHKAWA and Yuya OKAMOTO
}

\begin{abstract}
A new seismic retrofitting technique using compressive bracings for existing piloti-type reinforced concrete (R/C) frames has been proposed. The bracing is composed of steel pipes filled with high-strength mortar with its ends being able to resist only compressive force. This makes carrying out seismic retrofit easier, lowers the cost, and also minimizes the time spent.

A model is proposed in this paper to predict the envelop curve of lateral load versus story drift angle in the strengthened story after employing the compressive bracings. Calculations are presented to predict the axial stiffness and axial strength of the bracing, as well as the bearing strength and the partial bearing stiffness of the beams jointed to the bracing. Comparison between the experimental and theoretical values shows that the theoretical values predict the experimental values reasonably accurate.
\end{abstract}

Keywords : Piloti-Type Frame, Reinforced concrete, Seismic retrofitting, Bracing, Seismic Performance ピロティ架構, 鉄筋コンクリート, 耐震補強, ブレース, 耐震性能

1.はじめに

1995 年兵庫県南部地震でピロティ架構の鉄筋コンクリート造 (以後, RC) 建物に大きな被害が生じたことは周知のとおりである。この形式の建物 は既存建物として多く存在しており，耐震補強を施す必要がある。

特に民間建物に多く, 経済的理由によりほとんど補強は行われて いない。簡易な補強方法が求められている。本研究ではピロティ架 構を 1 階に RC 柱だけが設けられ，2 階以上では RC 壁が設けられる架 構と定義し, 耐震性能が劣り, 民間建物に多い図 1 (a) に示す 1 スパ ンの架構を対象にする。

塩屋ら ${ }^{1)}$ はピロティ架構の構造的特徴を利用して補強工事の範囲 と工事量を少なくする簡易な補強方法を提案し, 部分架構骨組の加 力実験を行い, その耐震性能を明らかにしている。

本論文ではその耐震性能の評価に用いるため, 補強するピロティ 層の層せん断力ー層間変形角関係の評価方法を提案する。

本論文の主な内容は, 補強概要と設計方針, 骨組の弾塑性解析に よる層せん断力ー層間変形角関係の特徵, そのモデル化と評価方法, 補強設計で必要となるブレースの軸剛性と軸耐力の評価式，および ブレースと梁の接合部の剛性と支圧耐力の評価式，などである。

層せん断力ー層間変形角関係の評価の一部では文献 2) の剛性と変 形の評価式を用い，ブレースの剛性・耐力の評価では文献 3) の実験 と評価方法に再考察を加えてそれらの評価式を整理し, ブレースと 梁の接合部の剛性と支圧耐力の評価では文献 5）6）7）11）の実験結果ま たは解析方法を基に簡略化してそれらの評価式を整理している。

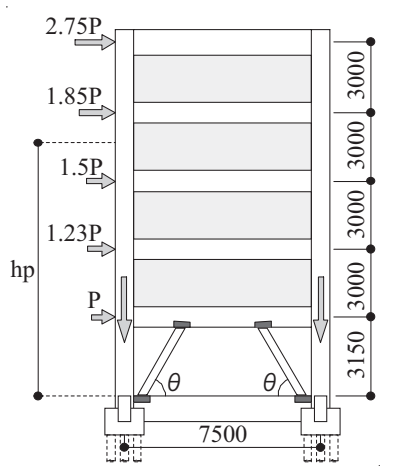

(a) 対象にする架構と補強 図1一補胎方法と加力实轵1)で

\section{2. 補強方法の概要と設計方針および既報の実験概要} 2. 1 補強方法の概要

図 1 ( a ) に補強の形状を示す。ピロティ架構は壁と一体になった 2 階梁と, 基礎梁を含めたフーチングの, 剛性と強度が極めて大きい と考えられる。本補強法はそれらの部分を連結するように圧縮抵抗 だけするブレースを設置する。ブレースは左右に設置する。ブレー スと上下の梁の接合部 ( 以後, 梁との接合部) は既存の梁を部分的には つり取り，ブレースと一体的に無収縮モルタルを充填する。既存部分 の工事範囲は梁の接合部だけである。2 階梁側には両端にナットを固 定したボルトを 2 本, 設置してブレースと 2 階梁を連結する。基礎梁 側には片側頭付磨き丸鋼を 2 本，頭を基礎梁側にしてブレース軸に平

Assoc. Prof., Dept. of Architecture and Architectural Eng., Kagoshima University, Dr. Eng. Takenaka Koumuten Co., Ltd.

Graduate Student, Dept. of Architecture and Architectural Eng., Kagoshima University 
行に設置する ${ }^{1)}$ 。ブレースに引張力が生じると, 図 1 ( c) に示すように 基礎梁とブレースの水平の境界でモルタルに分離ひび割れが生じ, 磨 き丸鋼をガイドにしてブレース端が滑り，圧縮力を受けると同様にブ レース端が滑り，分離面がずれないように閉じる仕組みになっている。

このようにしてブレースを引張抵抗させないため, 上下の梁との 接合部を簡素にできる。ブレースは鋼管に高強度のモルタルを充填し た圧縮材を用いて断面を小さくし, 設置角度 $\theta$ を $60^{\circ}$ 以上とする ${ }^{1)}$ 。 これにより, 補強による内部空間への制約をできるだけ小さくする。 本補強方法と既往の研究との位置づけは文献 1) を参照されたい。

\section{2 本補強の力学的狙いと目指す破壊形式}

本補強の力学的狙いは圧縮抵抗ブレースの設置によりピロティ階の 水平剛性と水平耐力を増大させ, 圧縮側の柱 ( 以後, 圧縮柱) の変動軸 力の増大を抑制することである。詳細は文献 1) を参照されたい。

本補強により目指す架構の破壊形式は, まずは架構の全体曲げ破 壊形式で, 架構の形状・寸法・重量によりそれが不可能な場合には, 基礎の浮き上がりに伴う架構の全体回転の形式, つぎにブレースを 圧縮降伏させて高い水平耐力で層をせん断降伏させる形式である。

このほか, ブレースと梁の接合部を支圧破壊させる形式や，ブ レースを座屈させる形式も考元られるが, その支圧破壊では梁に脆 性破壊が生じ, またブレースの座屈では上下のブレースの端部では 引張抵抗ができないように接合を簡素なものにしているため, それ らの破壊が生じた後, ブレースが倒れるなどの危険性がある。

本補強では, 梁の接合部の支圧破壊やブレースの座屈が想定され る状況では, それらの破壊形式の水平耐力よりも, ブレースの圧縮 降伏耐力が小さくなるように制御して圧縮降伏させる破壊形式を選
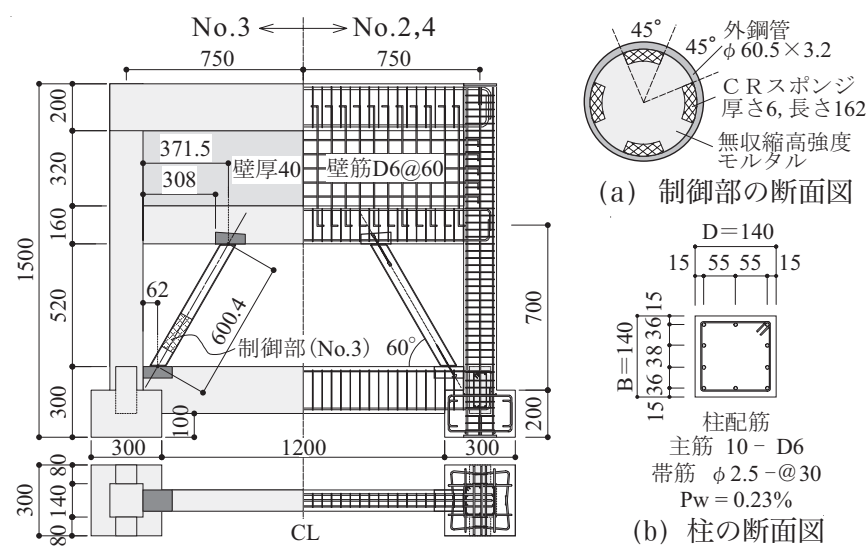

(a) 制御部の断面図

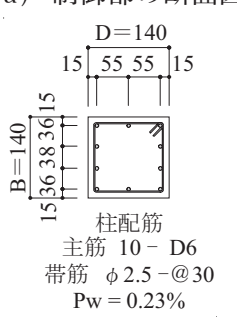

(b) 柱の断面図

図2 既報 ${ }^{1)}$ の部分架構試験体

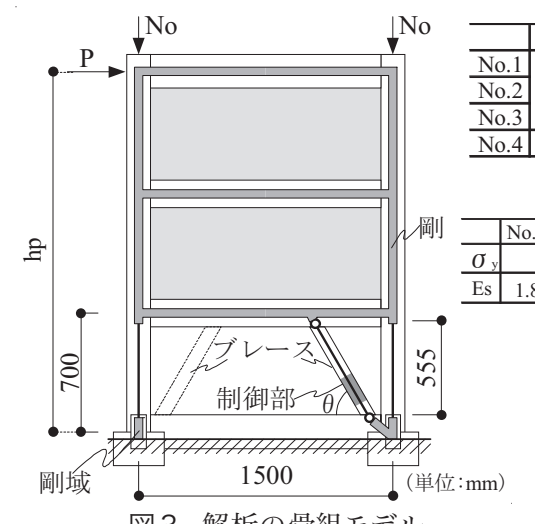

\begin{tabular}{|c|c|c|c|}
\hline & $\mathrm{hp}(\mathrm{mm})$ & $\mathrm{No}(\mathrm{kN})$ & $\eta$ (軸力比) \\
\hline No.1 & \multirow[b]{2}{*}{1926} & \multirow{3}{*}{79.1} & 0.15 \\
\hline No. 2 & & & \\
\hline$\frac{\text { No.3 }}{\text { No.4 }}$ & 2226 & & 0.13 \\
\hline
\end{tabular}

図3 解析の骨組モデル
択する。当然，目指す破壊機構に達する以前に左右の柱がせん断破壊 しないことを確認する必要がある。せん断破壊する場合には柱のせ 几断補強を行って本補強法を用いることになる。また 2 階以上の部 分に水平方向や鉛直方向のせん断破壊や曲げ破壊が生じないことを 確認する必要がある。

\section{3 既報の実験概要 ${ }^{1)}$}

既報の実験では図 2 に示す試験体を 4 体製作し，比較用の無補強試 験体No.1，ブレースが接合する梁を支圧破壊させた試験体 No.2，ブ レースを圧縮降伏させた試験体 No.3, 全体曲げ降伏させた試験体 No.4 の実験を行っている。加力は図 1 ( b ) に示すように左右の鉛直荷重を 変動させ, 図 1 (a) の水平力の重心までの高さ $\mathrm{hp}$ 注1) が一定になるよ うに制御して繰り返しの水平加力を行っている。

ブレースを圧縮降伏させたNo.3 では, 図 2 の左に示すようにブ レースの基礎梁側の位置に鋼管内部に鋼管の横拘束力を隇少させる 区間 ( 以後, 制御部) を設け, その部分のモルタルを圧縮降伏させてい る。これは, 梁との接合部が支圧破壊する時にブレースに生じる軸力 より, ブレースの圧縮降伏耐力が小さくなるように制御部を設計し, 梁との接合部の支圧破壊を回避するためである。同図 ( a ) に制御部位 置のブレースの軸断面を示す。鋼管の内側にクロロプレンゴムスポ ンジを貼り付ている。ブレースの圧縮降伏耐力はその断面のモル夕 ルの圧縮耐力で制御する。そこではモルタルの圧縮破壊後に生じる 耐力低下を, 鋼管に触れるモルタル部分が鋼管より横拘束力を受け て抑制する仕組みになっている。制御部の圧縮特性は一軸圧縮実験 で調べられており文献 1) を参照されたい。

\section{3. ピロティ層の層せん断カー層間変形角関係の解析}

\section{1 解析方針と解析条件}

補強するピロティ層において, ブレースと柱が負担する水平せん断 力と層間変形角の関係や最大耐力が決定する過程を明らかにすること を目的に骨組の静的弾塑性解析を行った。

加力は一方向とした。弾塑性骨組解析ソフトSNAPを使用した。 図 3 にモデル化したNo.3 試験体の骨組を示す。この試験体では, ブレースを圧縮降伏させるためにブレースに制御部を設けた。No.1 はブレースを設置しないで, No.2 と No.4 は制御部を設けないブレー スを設置した。2 階以上は剛体とし，ピロティ層の左右の柱と圧縮ブ レースは弾塑性体として抵抗するものとした。引張ブレースは無視 した。柱とブレースの下端の節点は固定端とした。柱の上下では梁 との接合部内に剛域を設け, 柱梁接合部の境界面から, その接合部 内の剛域端までの鉛直距離を柱せい D の $1 / 8$ とした。

本章では層せん断力ー層間変形角関係において柱とブレースの負 担水平力の挙動の特徴を明らかにすることを主目的にしたため, ブ レースと梁の接合部は支圧破壊を考慮する詳細なモデルとしなかつ

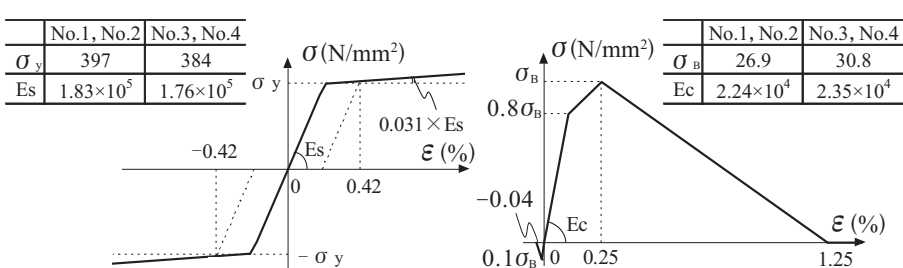

(a) 柱主筋 (b) コンクリート

図 4 解析で仮定した材料特性

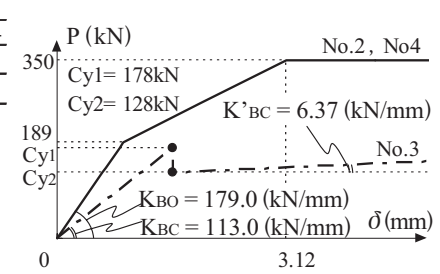

(c) ブレースの一軸圧縮特性 


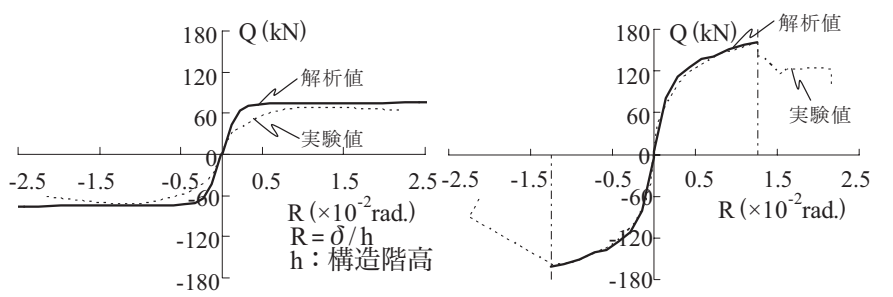

(a) No.1

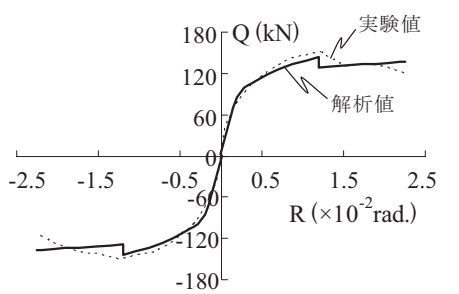

(c) No.3

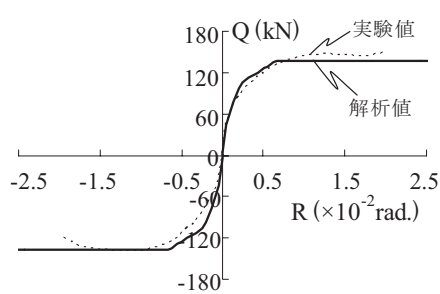

(d) No.4

図 5 ピロティ層の層せん断力ー層間変形角関係の解析結果と実験結果の比較

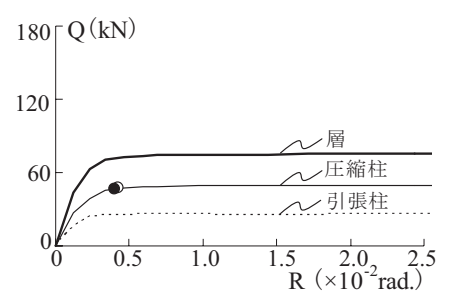

(a) No.1

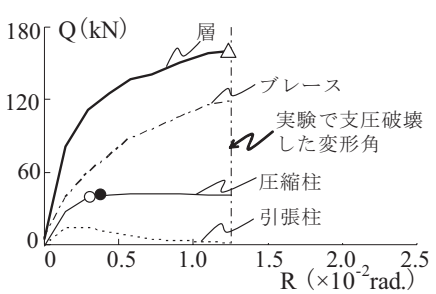

(b) No.2

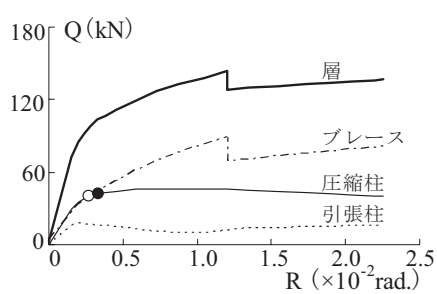

(c) No.3

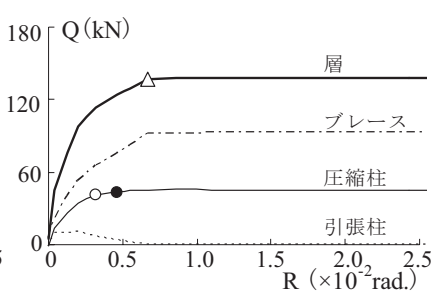

(d) No.4

図 6 解析による各部材の負担水平力と層間変形角の関係

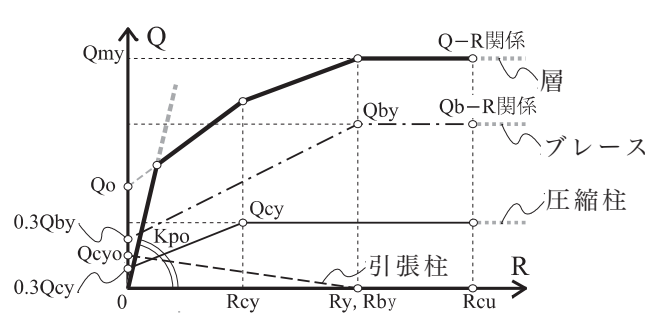

（a）全体曲げ降伏する場合

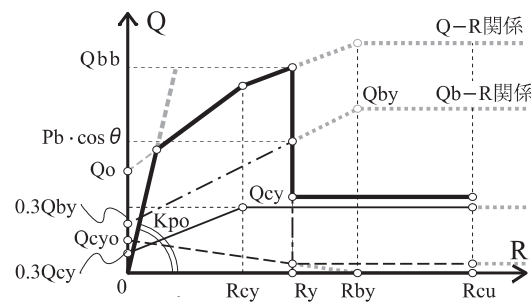

(b) ブレース接合部が支圧破壊する場合

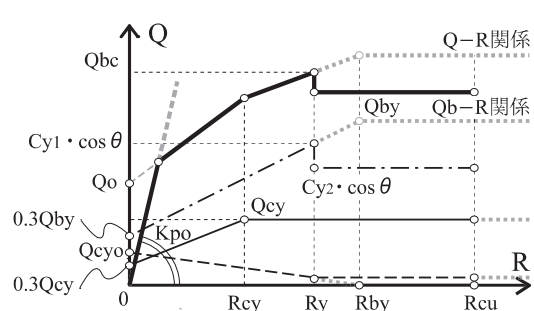

（c）ブレースを圧縮降伏させる場合

図 7 ピロティ層の層せん断力ー層間変形角関係のモデル化の模式図

た。ここではブレース長を上下の梁の内部まで延長させる形で単に 梁で生じる局部的変形を表すモデルとした。その延長は柱の上下の 剛域端の高さまでとした。補強設計で用いる接合部の剛性と耐力の 評価方法は 5.3 節と 5.4 節で後述する。柱には材端にマルチスプリン グを設定して弾塑性解析を行った。材端のスプリングの区間は材長 の $10 \%$ とした。

図 4 に材料実験に基づいて仮定した材料の応力ーひずみ関係を示す。 柱主筋は明瞭な降伏棚が生じないで降伏後, 直ちにひずみ硬化が生 じるタイプとしている。ブレースは一軸のトラス材とし, No.3では制 御部とそれ以外の部分に分けた。ブレースの軸剛性と耐力は 5.1 節と 5.2 節で後述する方法により設定した。

加力は左右の柱に一定の鉛直荷重を作用させ , 水平荷重を $\mathrm{hp}$ の高 さに作用させた。No.4 試験体は hp を実験に合わせて高くした。

図 3 中に設定した hp と 1 階の柱の長期軸力 No を示す。解析は水平 荷重位置の水平変形を漸増させる変形制御とした。

\section{2 解析結果}

図 5 にピロテイ層の層せん断力ー層間変形角関係の解析結果と実験 結果を比較して示す。変形角は 1 階の階高 $(700 \mathrm{~mm})$ で除している。 No.2では実験で梁が支圧破壞した変形角までを太実線で示す。いず れの解析值も実験の包絡線 ( 破線) をほぼ推定している。

図 6 にピロティ層の, ブレースと柱の負担水平力の変化を示す。横 軸は層間変形角である。これらは解析結果である。○は圧縮柱の柱脚 が曲げ降伏した時点, ○は柱頭が曲げ降伏した時点, $\triangle$ は引張側の 柱 ( 以後, 引張柱) が全引張降伏した時点である。

図 6 (d) の全体曲げ降伏した No.4 は, 圧縮柱の柱脚が曲げ降伏して 圧縮柱の負担水平力がほぼ一定になり，ブレースの負担水平力は引張
柱が全引張降伏した以降, 一定になっている。引張柱の負担水平力は 変形角の増加に伴い減少し, 全引張降伏する時点で零になっている。 図6 (b) のNo.2 は引張柱が全引張降伏する変形角の解析值 (図中 $\triangle$ ) と, 実験で支圧破壊した変形角 ( 図中縦の一点鎖線) がほぼ同じになり, 実験 ${ }^{1)}$ で報告したように全体曲げ降伏する直前で支圧破壊した破壊 状況とほぼ一致する。

図 6 ( c ) の No.3 は圧縮柱の柱頭と柱脚が曲げ降伏して圧縮柱の負 担水平力が一定になり，その後，ブレースの制御部のモルタルが圧 縮降伏し, 荷重低下が生じて水平耐力に達している。この後, ブレー スの負担水平力はほぼ一定となっている。引張柱は, その水平耐力 時に負担していた水平力を以後, 維持している。

今回の解析では，全体曲げ降伏させる場合とブレースを圧縮降伏 させる場合で水平耐力が決定した以降に耐力低下が生じる時点の終 局変形を表現できない。図 6 (c) と図 6 (d) の結果に基づくと水平耐力 が決定した以降では圧縮柱の水平負担力は層の水平耐力の $30 \%$ ～ $32 \%$ となった。補強層は不静定次数が小さいため圧縮柱の曲げ降伏後の 耐力低下は, 補強層の耐力低下につながる。次節ではこれらのこと を基に簡便的に, 圧縮柱の終局変形時点を, 全体曲げ降伏させる場 合とブレースを圧縮降伏させる場合で補強層の水平耐力を維持でき る限界の終局変形時点と仮定する。ここでの補強層とは補強する 1 スパンのピロティ層である。

4. ピロティ層の層せん断カー層間変形角関係のモデル化と評価 モデル化と評価は一般の耐震診断を想定して簡略的なものとする。

4. 1 層せん断カー層間変形角関係のモデル化 前章の解析結果を基に, 補強するピロティ層の層せん断力ー層間変 
形角関係をモデル化する。図 7 にそれらの模式図を示す。図7 (a) は 全体曲げ降伏する場合である。初期の弾性範囲の層せん断力一層間 変形角関係は補強層の水平方向の弾性剛性を用いて表される層せ し断力と層間変形角の関係とする。

弾性以降はつぎの関係によるものとする。圧縮柱とブレースはそ れぞれの負担水平力が最大になる時点 $\mathrm{Q} c \mathrm{y}, \mathrm{Qby}$ までは, 変形角が零 で最大負担水平力 $\mathrm{Qcy}, \mathrm{Qby}$ の $30 \%$ をせん断力とする点と，それぞれ の Qcy, Qby の時点を結ぶ直線 (図 7 (a) の細実線, 一点鎖線) で表す。

これは耐震診断基準9) で用いる, 柱や耐震壁が曲げ降伏するまでの 荷重一変形関係のモデル化に準じている。圧縮柱は曲げ柱に対応し, ブレースの負担水平力は, 耐震壁で壁縦筋を無視して引張柱が引張 降伏して曲げ破壊する場合の水平せん断力と見なすことになる。同 基準では $30 \%$ の根拠は述べられていないが, 一般の鉄筋コンクリート 構造では，そのようになる配筋を行っていると考えられる。

引張柱は, 変形角が零で柱軸力を零とした柱の曲げ降伏時のせん 断力 $\mathrm{Q}$ cyo をせん断力とする点と, 全体曲げ降伏する変形角 Ry でせん 断力が零となる点を結ぶ直線 ( 破線) とする。 R y 以降は各部材とも, その時の負担水平力を保持するものとする。ピロティ層の層せん断 力一層間変形角関係 (太実線, $\mathrm{Q}-\mathrm{R}$ 関係) は, これらの各関係の水平 力を加算したものとする。この降伏機構の終局変形角は圧縮柱の終 局変形角 Rcu に等しいものとする。このモデル化では弾性剛性 K po, 全体曲げ降伏する時のブレースの負担水平力 $\mathrm{Qby}$ と変形角 $\mathrm{R} b y$, 圧縮 柱の柱頭と柱脚が曲げ降伏する時のせん断力 $\mathrm{Q}$ c y と変形角 R c y お よ び終局変形角 R cu, 引張柱の曲げ降伏時のせん断力 $\mathrm{Q}$ c yo が必要にな る。これらの評価方法は 4.2 節以降で述べる。

図 7 ( b ) はブレースの梁側の接合部が支圧破壊する場合である。支 圧破壊するまでは全体曲げ降伏する場合の関係をたどる。しかし， ブレースの軸力 $\mathrm{C}_{\mathrm{B}}$ が接合部の支圧耐力 $\mathrm{Pb}$ になると支圧破壊する。 支圧耐力 $\mathrm{Pb}$ が与えられると, その余弦成分 $\mathrm{Pb} \cdot \cos \theta$ をブレースの 負担水平力として $\mathrm{Qb}-\mathrm{R}$ 関係でその時の層間変形角 $\mathrm{Ry}$ が特定でき, 支圧破壊する層せん断力 $\mathrm{Qbb}$ も全体曲げ降伏する場合の $\mathrm{Q}-\mathrm{R}$ 関係か ら特定できる。支圧破壊以降は圧縮ブレースの負担水平力を零とし, 圧縮柱と引張柱は支圧破壊時の負担水平力を維持できるものとする。 補強層の終局変形角は圧縮柱の終局変形角 Rcu とする。

図 7 ( c ) はブレースを圧縮降伏させる場合である。ブレースの負担 水平力が, ブレースの降伏軸力 $\mathrm{Cy} 1$ の余弦成分 $\mathrm{Cy} 1 \cdot \cos \theta$ に達した時に ブレースは圧縮降伏するものとする。図 7 ( b ) と同様にその時の層せ ん断力 $\mathrm{Qbc}$ と層間変形角 Ry も特定できる。ブレースは図 4 (c) で示し たように制御部のモルタルの圧縮破壊時の軸力 $\mathrm{Cy} 1$ と, その後に安定 する降伏軸力 $\mathrm{Cy} 2$ に差があるので, 圧縮降伏直後は耐力低下が生じる。 これ以降は圧縮柱が終局変形角 Rcu に達するまでは耐力を一定とする。

\section{2 弾性剛性 Kpo}

層が水平方向に単にせん断変形すると仮定した場合の弾性の水平剛 性を用いる。水平剛性の評価式 2) ( 1) 式に示す。弾性範囲では引張 ブレースも抵抗するので, それを考慮している。実際は上階の転倒 モーメントも影響を与える。これについては文献 2)で, その影響も 述べているので，そちらを参照されたい。

$$
\mathrm{Kpo}=2 \cdot\left(\mathrm{cKo}+\mathrm{KBe} \cdot \cos ^{2} \theta\right)
$$

ここに, $\mathrm{cKo}\left(=12 \cdot \mathrm{EIe} / \mathrm{ho}^{3}\right)$ : 逆対称モーメントの柱の水平剛性

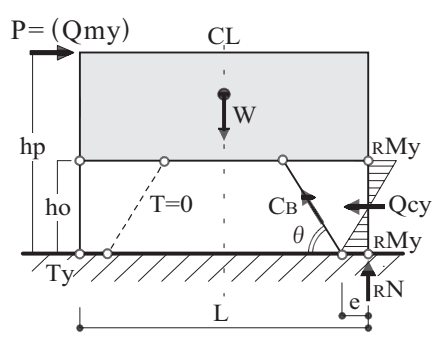

図 8 全体曲げ降伏時の内力

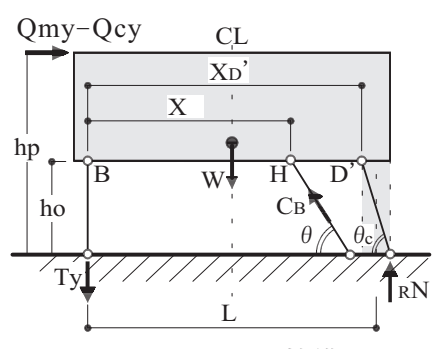

図 9 トラス機構
EIe : 柱の弾性曲げ岡性, ho: 柱内法長さ, Kве : ブレースの 軸剛性で 5.1 節の (18) 式による。 $\theta$ : ブレースの設置角度

4.3 全体曲げ降伏時の水平耐力 $\mathrm{Qmy}$ と各部材の負担水平力 $\mathrm{Qby}, \mathrm{Qcy}$ 図 8 に内力の状態を示す。水平力 $\mathrm{P}$ を $\mathrm{Qmy}$ と同じとしている。引 張柱が全引張降伏し, 圧縮柱の柱脚が曲げ降伏するため, 水平耐力 Qmy は圧縮柱の柱脚まわりのモーメントの釣り合いより (2) 式で表さ れる。本補強では圧縮ブレースにより圧縮柱側のフーチングに大き な水平力が伝達し, 引張柱側のフーチングとの間に相対的に開く水 平変位が生じる可能性がある。これに伴い基礎梁に引張力が生じて基 礎梁の曲げ降伏モーメントが減少し, 圧縮柱の柱脚が曲げ降伏する以 前に基礎梁が曲げ降伏する可能性もある。この場合には基礎スラブの 回転抵抗モーメントも加算した検討も行い, 状況に応じて圧縮柱の柱 脚のモーメントを減じる必要がある。

$$
\text { Qmy }=\left(\mathrm{Ty}_{\mathrm{y}} \cdot \mathrm{L}+0.5 \cdot \mathrm{W} \cdot \mathrm{L}+{ }_{\mathrm{R}} \mathrm{My}-\mathrm{C}_{\mathrm{B}} \cdot \mathrm{e} \cdot \sin \theta\right) / \mathrm{hp}
$$

ここに, Ty : 引張柱の主筋の全引張降伏力 $(=\mathrm{ag} \cdot \sigma \mathrm{y}), \mathrm{ag}$ : 主筋の全断 面積, $\sigma_{\mathrm{y}}$ : 主筋の降伏強度, L: スパン長さ $\mathrm{W}: 2$ 階以上の長期荷重で, 1 階の左右柱の長期軸力の和 R My : 圧縮柱の曲げ降伏モーメントで (3) 式による。

$\mathrm{My}=0.8 \cdot \mathrm{a} \cdot \mathrm{D} \cdot \sigma \mathrm{y}+0.5 \cdot \mathrm{N} \cdot \mathrm{D} \cdot\{1-\mathrm{N} /(\mathrm{Fc} \cdot \mathrm{B} \cdot \mathrm{D})\}$ ただし, $0 \leqq \mathrm{~N} \leqq 0.4 \cdot \mathrm{Fc} \cdot \mathrm{B} \cdot \mathrm{D} \quad$ 記号と範囲以外は文献 8$)$ を 参照。軸力 $\mathrm{N}$ は圧縮力を正とする。 $\mathrm{F}_{\mathrm{c}}$ ：コンクリートの圧 縮強度, $\mathrm{B}$ : 柱幅, D : 柱せい, $\mathrm{C}_{\mathrm{B}}$ : ブレースの圧縮軸力 $\mathrm{e}:$ ブレースの下端から圧縮柱の軸までの水平距離 $\mathrm{hp}$ ：ピロティ階の基礎梁上端から水平荷重 $\mathrm{P}$ までの高さ

（３）式において圧縮柱の軸力 $\mathrm{R} \mathrm{N}$ が必要になる。3.2 節で述べた図 6 （b）（c）（d）の解析の結果，ブレースで補強した場合，いずれの破壊形 式でも水平耐力に達する以前に圧縮柱の柱頭と柱脚は曲げ降伏して いる。ここでも全体曲げ降伏時には圧縮柱の柱頭と柱脚は曲げ降 伏しているとして軸力 $\mathrm{R} N$ を近似する。引張柱は水平抵抗しないので, ピロティ層の水平方向と鉛直方向の力の釣り合いは (4) 式と (5) 式で表

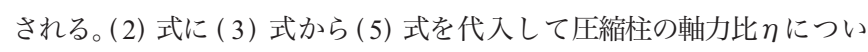
て整理すると, $\eta$ は (6) 式で表され, 軸力 $\mathrm{R} \mathrm{N}$ は(7) 式で表される。

$$
\begin{aligned}
& \text { Qmy }=\sum_{\mathrm{R} M y} / \mathrm{ho}+\mathrm{C}_{\mathrm{B}} \cdot \cos \theta \\
& \begin{aligned}
\mathrm{W}=\mathrm{RN}+\mathrm{C}_{\mathrm{B}} \cdot \sin \theta-\mathrm{Ty} \\
\eta=\left\{-\mathrm{b}_{1} \pm\left(\mathrm{b}_{1}{ }^{2}-4 \cdot \mathrm{a}_{1} \cdot \mathrm{c}_{1}\right)^{1 / 2}\right\} /\left(2 \cdot \mathrm{a}_{1}\right) \\
\mathrm{a}_{1}=2 \mathrm{hp} / \mathrm{ho}-1 \\
\mathrm{~b}_{1}=1-2 \mathrm{hp} / \mathrm{ho}+2 \mathrm{hp} \cdot \cot \theta / \mathrm{D}+2 \mathrm{e} / \mathrm{D} \\
\mathrm{c}_{1}=(\mathrm{L} / \mathrm{D}-2 \mathrm{hp} \cdot \cot \theta / \mathrm{D}-2 \mathrm{e} / \mathrm{D}) \cdot \eta \mathrm{t} \\
\quad+\{2 \mathrm{~L} / \mathrm{D}-2 \mathrm{hp} \cdot \cot \theta / \mathrm{D}-2 \mathrm{e} / \mathrm{D} \\
\quad+(1.6-3.2 \mathrm{hp} / \mathrm{ho}) \cdot \mathrm{pt} / \mathrm{pg}\} \cdot\left(\mathrm{pg} \cdot \sigma_{\mathrm{y}} / \mathrm{Fc}\right)
\end{aligned}
\end{aligned}
$$




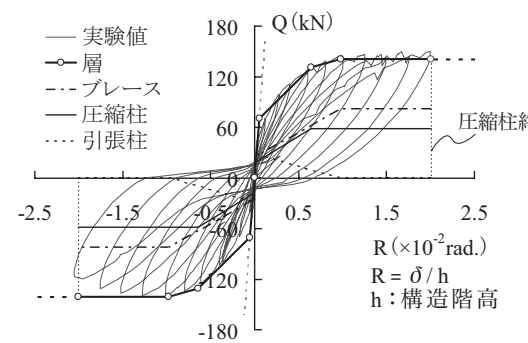

（a）全体曲げ降伏した No.4 試験体

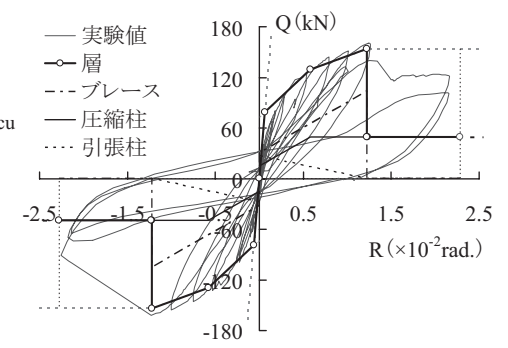

(b) ブレース接合部が支圧破壊した No.2 試験体

図 104 章の評価方法による計算結果と実験結果の比較

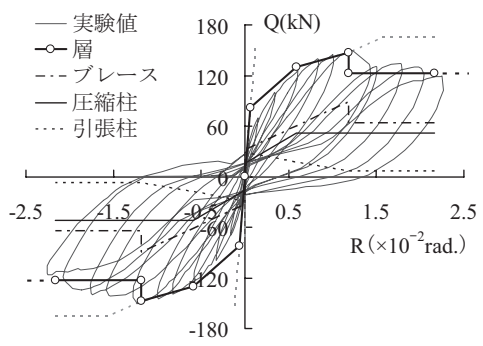

（c）ブレースが圧縮降伏した No.3 試験体
$\mathrm{RN}=\eta \cdot \mathrm{Fc} \cdot \mathrm{B} \cdot \mathrm{D}$

ここに, $\Sigma_{\mathrm{R}} \mathrm{M}_{\mathrm{y}}$ : 圧縮柱の柱頭と柱脚の曲げ降伏モーメントの和 $\mathrm{R} \mathrm{N}$ : 降伏時の圧縮柱の軸力, $\eta \mathrm{t}=\mathrm{W} /\left(\mathrm{Fc}_{\mathrm{c}} \cdot \mathrm{B} \cdot \mathrm{D}\right), \mathrm{pt}$ : 引張鉄筋比, pg: 柱全主筋比

(4) 式を $\mathrm{C}_{\mathrm{B}}$ について整理して (2) 式に代入し, Qmy について整理す ると(8) 式が得られる。(7) 式による軸力 $\mathrm{RN}$ を用いて(3) 式より $\mathrm{RMy}$ 算出し，(9) 式により圧縮柱のせん断力 Qcy を算出する。これらの $\mathrm{RMy}$ と Qcy を(8) 式に代入して全体曲げ降伏する場合の水平耐力 $\mathrm{Qmy}$ を算 出する。 (4) 式と (9) 式よりブレースの軸力 $\mathrm{C}$ в (10) 式で表される。ブ レースの負担水平力 $\mathrm{Qby}$ もその $\mathrm{C}_{\mathrm{B}}$ を用いて (11) 式で表される。

$$
\begin{aligned}
& \mathrm{Qmy}=(\mathrm{Ty} \cdot \mathrm{L}+0.5 \cdot \mathrm{W} \cdot \mathrm{L}+\mathrm{RMy}+\mathrm{Qcy} \cdot \mathrm{e} \cdot \tan \theta) /(\mathrm{hp}+\mathrm{e} \cdot \tan \theta) \\
& \mathrm{Qcy}=\sum_{\mathrm{RMy}} / \mathrm{ho} \\
& \mathrm{C}_{\mathrm{B}}=(\mathrm{Qmy}-\mathrm{Qcy}) / \cos \theta \\
& \text { Qby }=\mathrm{C}_{\mathrm{B}} \cdot \cos \theta=\mathrm{Qmy}-\mathrm{Qcy}
\end{aligned}
$$

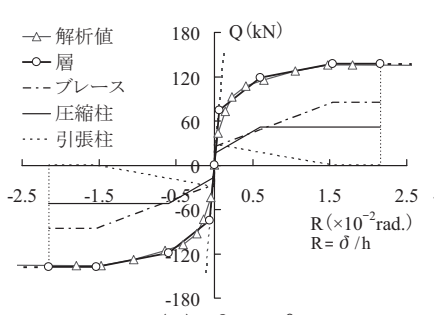

(a) $\theta=65^{\circ}$

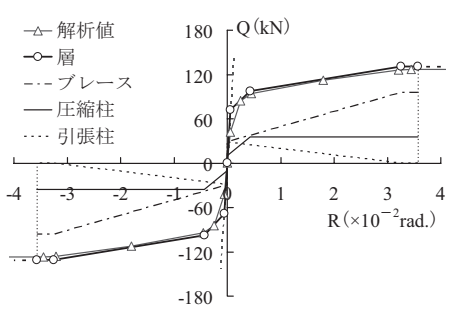

(b) $\theta=70^{\circ}$
図 $11 \theta$ を変化させた場合の解析結果と 4 章の方法による計算結果の比較

られると, 変形状態が決定して層間変形を評価できる。引張柱の軸変 形は柱主筋の降伏ひずみから適切に仮定できる。また圧縮柱とブレー スの軸変形は, それらの軸剛性を適切に与え, (7) 式と (10) 式から求め られる軸力を用いて近似できる。この考え方に基づき文献2) では層間 変形の評価式を誘導している。それを層間変形角で表すと(13) 式となる。 これをRby の評価式とする。詳細は文献2)を参照されたい。

$$
\begin{aligned}
& \text { Rby }=\left(\mathrm{a}_{5} \cdot \mathrm{b}_{5}-\mathrm{c}_{5}\right) /\left\{\left(\mathrm{a}_{5} \cdot \mathrm{d} 5-\mathrm{e}_{5}\right) \cdot \mathrm{h}\right\} \\
& \text { ここに, } \mathrm{a}_{5}=\left(\mathrm{X}_{\mathrm{H}}+\mathrm{j} / 2\right) \cdot \sin \theta /\left\{\left(\mathrm{X}_{\mathrm{D}}{ }^{\prime}+\mathrm{j} / 2\right) \cdot \sin \theta_{\mathrm{c}}\right\} \\
& \mathrm{b}_{5}={ }_{\mathrm{R}} \mathrm{N} /\left(\alpha_{\mathrm{c}} \cdot \mathrm{K}_{\mathrm{c}} \cdot \sin \theta_{\mathrm{c}}\right)+\varepsilon_{\mathrm{y}} \cdot \mathrm{ho}_{\mathrm{o}} \cdot \sin \theta_{\mathrm{c}} \\
& \mathrm{C}_{5}=\mathrm{C}_{\mathrm{B}} / \mathrm{K}_{\mathrm{Be}}+\varepsilon_{\mathrm{y}} \cdot \mathrm{ho}_{0} \cdot \sin \theta \\
& \mathrm{d} 5=\cos \theta \mathrm{c}-\mathrm{j} / \mathrm{ho} \cdot \sin \theta \mathrm{c}, \quad \mathrm{e}_{5}=\cos \theta-\mathrm{j} / \mathrm{ho} \cdot \sin \theta
\end{aligned}
$$

$\mathrm{X}_{\mathrm{H}}$ は図 9 の点 $\mathrm{B}$ から点 $\mathrm{H}$ までの水平距離, $\mathrm{X}_{\mathrm{D}}$ 'は点 $\mathrm{B}$ から点 D’までの水平距離 $(=\mathrm{L}-\mathrm{g} ・ \mathrm{D} / 2)$ で $\mathrm{g}$ は 0.8 とする。 Dは柱せい, $\mathrm{j}$ は圧縮鉄筋と引張鉄筋の距離で一般には $0.8 \mathrm{D}$ とする。 $\theta \mathrm{c}$ は圧縮柱のアーチの角度で $\tan ^{-1}(\mathrm{ho} / 0.8 \mathrm{D})$ とする。 $\mathrm{RN}$ は (7) 式による。 $\alpha_{\mathrm{c}}$ は柱の軸剛性低下率で 0.9 とする。 $\mathrm{Kc}$ は柱の 弾性軸岡性で $\mathrm{Ec} \cdot \mathrm{Ac} / \mathrm{ho}, \mathrm{Ec}$ はコンクリートのヤング係数, Ac は柱断面積， $\varepsilon_{\mathrm{y}}$ は柱主筋の降伏ひずみで一般に $0.2 \%$ で, 降 伏強度を $0.2 \%$ オフセットで決める場合には $0.4 \%$ とする。 Cв は (10) 式による。 Kве は 5.1 節の (18) 式による。

\section{5 圧縮柱の終局変形角 Rcu}

$\mathrm{Rcu}$ は 文献 9) の柱の終局変形角の評価式を用いて (14) 式で表す。

$$
\mathrm{Rcu}=(0.0667 \mathrm{cQsu} / \mathrm{cQmu}-0.06) \cdot \mathrm{ho} / \mathrm{h} \quad(\mathrm{rad} .)
$$

cQsu はせん断耐力であり，設計では設計式を用いるが，ここでは実 験值と比較するため修正広沢 mean 式8) と文献 10) で示した修正係数fの 式を用いる。cQmu は曲げ終局時せん断力であり，(9) 式の Qcy を用いる。

\section{6 層せん断力ー層間変形角関係の計算}

図 10 に上記の方法による計算結果と実験結果を比較して示す。計 算結果は概ね, 実験の包絡線を推定している。図 11 にNo.4 試験体の 架構でブレースの設置角度を $65^{\circ}$ と 70 そした場合の解析結果と本章 


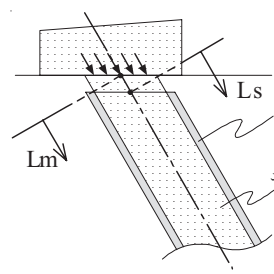

(a) 上梁側

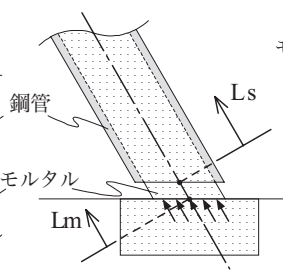

(b) 基礎梁側

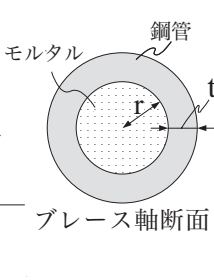

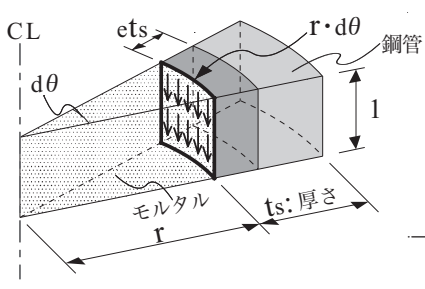

(b) 付着力と ets の関係

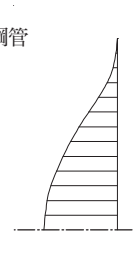

(a) 軸力

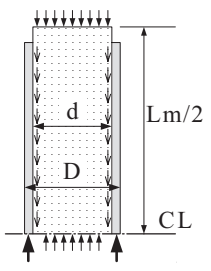

(b) 付着力

図 12 ブレース上下端の詳細

図 14 鋼管の軸力と付着力の分布

の方法による計算結果を比較して示す。解析は 3 章の方法による。 $\theta$ が大きくなると全体曲げ降伏する変形角が大きくなるが，本章の 方法による計算結果は解析の結果を近似している。これらのことか ら本章の評価方法により, 補強するピロティ層の層せん断力一層間 変形角関係の包絡線を評価できると判断できる。

5. ブレースと接合部の剛性と耐力の評価

層せん断力ー層間変形角関係の評価で必要となるブレースの軸剛性 と圧縮耐力，上下の梁側の接合部の剛性と支圧耐力の評価方法につい て述べる。前章の計算で用いた值は本章の評価方法に基づいている。

ここでは文献 3)，5），6），7），11）の実験結果または評価方法を用 いて，それらの項目を簡略的に評価する方法について述べる。

5. 1 上下の梁へのめり込み変形を考慮したブレ一スの軸剛性 $\mathrm{K}$ в

図 12 に示すようにブレースの両端ではモルタル部分が圧縮され, 両端では鋼管に直接, 圧縮力が伝達しない。このためブレースの軸 剛性に鋼管の軸剛性が全て有効に寄与できない。ブレース自体の軸 剛性 Kво はモル夕ル部分の軸剛性 K m に鋼管の軸剛性 Ks がある程度, 寄与するかたちで表される。これを式で表すと（15) 式となる。

$\mathrm{K}_{\mathrm{BO}}=\mathrm{Km}+\gamma \cdot \mathrm{Ks}$

ここに $, \mathrm{Km}=\mathrm{Em} \cdot \mathrm{Am} / \mathrm{Lm}, \mathrm{Ks}=\mathrm{Es} \cdot \mathrm{As} / \mathrm{Ls}$

$\mathrm{Em}, \mathrm{Es}:$ モルタルと鋼管のヤング係数

$\mathrm{Am}, \mathrm{As}$ : モルタルと鋼管の軸断面積

L m, Ls : 図 12 中に示すモルタル部分と鋼管の材長, ただし, ブレースに制御部を設ける場合には，それらの 材長から制御部の区間を除いたものとする。

L m と Ls には差があり, 厳密には, モルタル部分の上下の材端間の 相対変形と鋼管の全軸変形は異なる。しかし, 図 2 の架構試験体で は Ls が Lm に対する割合は 98\% で，実架構でも同程度とすることを前 提にし，その変形の違いによる影響は無視することにする。

上式における $\gamma$ が寄与する割合である。これは，モルタルと鋼管 の境界の付着応力ーすべり関係を仮定して数值解析により推定す ることもできるが，その計算作業は複雑になり，耐震診断の作業に は適しない。ここでは実用範囲に限定したブレースの一軸圧縮実験 $\left.{ }^{1)}, 3\right)$ に基づいて $\gamma$ を定める。鋼管はモルタルとの境界面の付着力を介し て材軸方向に縮む。鋼管の厚さ方向の範囲おいてブレース軸方向 の変形状態を考える。鋼管厚さ ts が厚い場合, 図 13 (a) に示すよう にその境界面に近い領域は, ブレース材軸方向に変形が生じてモ ルタルの軸方向変形を拘束する。これによりブレースの軸剛性は 増大する。これに較べ, その境界面から離れる鋼管の外周面に近 い領域は，材軸方向の変形は小さくなり，ブレースの軸剛性を増大 させる程度は小さくなる。すなわち，鋼管は厚さの範囲において一
様にブレースの軸剛性を増大させる変形状態とはならない。このこ とを考慮し，実際の鋼管の厚さより小さい，鋼管の見掛けの厚さ ets を定義して一軸圧縮実験のブレースの軸剛性の実験值に適合するよ うに設定する。

図 13 (b) に示すように材軸方向に単位長さで微少角度 $\mathrm{d} \theta$ により構成 される鋼管の要素を考える。 $\mathrm{r}$ は鋼管の内側の半径である。モルタル との境界面の面積は単位長さと要素の内側の周長 $\mathrm{d} \theta \cdot \mathrm{r}$ の積で表される。 その面積の付着応力の合力により図 13 (a) の鋼管の軸方向変形が生じる。 その面積内において付着応力の大きさを一定とすると, その合力の 大きさは面積の大きさと直接, 関係があることになる。d $\theta$ を単位角 度とすると，その面積は $\mathrm{r}$ で表される。 $\mathrm{r}$ が大きくなると，そこでの 付着合力は大きくなり, 前述の鋼管の軸方向変形が大きくなり, そ の分, 鋼管はブレースの軸剛性を増大させる。このため, 鋼管のブ レースの軸剛性への寄与を表す見掛けの厚さ et s は大きくなる。すな わち ets はr r 関係があることになる。ここでは $\mathrm{r}$ に対する ets の比 $\mathrm{ets} / \mathrm{r}$ を k とし, 軸剛性の実験值に適合するように $\mathrm{k}$ を定める。

図 14 に鋼管の上半分の軸力と付着力の分布を模式的に示す。鋼管の 軸力は上端からの付着力の合力に等しいので材軸方向に変化する。そ の変化勾配は, 付着力の合力の材軸方向の変化勾配と同じで, 材軸の 単位長さあたりの鋼管内径の面積での付着力の合力で表される。材軸 上で同じ位置の付着応力は内周では同じと考えられるので, 付着力の 合力の変化勾配には面積を表す内周長が大きな影響を与える。鋼管の 軸力分布は, 変化勾配と変化区間で決まる。このため, 形状的には内 周長と材長 $\mathrm{L}$ の比の影響を受ける。内周長はその直径 $\mathrm{d}$ と円周率の積で, 軸力分布に大きな影響を与える形状的因子として L/d を考える。当然, 有効厚さ ets もこの影響を受けるが, 実験で用いた試験体の L/d が実 用範囲内で，その範囲に限定して ets を整理する場合， L/d の変化 の影響を特に考慮する必要はない。ここではdを近似的に鋼管の 外径 D と見なす。

塩屋らはブレースの座屈実験 ${ }^{3)}$ を行っている。図 15 に試験体の形 状と寸法および加力状況を示す。縮尺は実大の約 $1 / 2.7$ である。実用 範囲を想定して 5 種類の形状比 $\mathrm{L} / \mathrm{D}$ を選定している。実験では $\mathrm{L}$ を座 屈長さLk として計画している。詳細は文献3）を参照されたい。

図 16 (a) から図 16 (e) にその実験の圧縮荷重一変形関係を示す。示 した試験体は座屈して耐力が決定している。また図 16 (f) は第 2 章で 述べた架構実験と同時に行ったNo.2 試験体のブレースの圧縮実験結 果 ${ }^{1)}$ である。図中には鋼管を無視して計算したモルタルだけの圧縮耐 力 $\mathrm{Nm}$ を水平の点線で示す。5.2.1 節で後述するが，ブレース端に局部 補強を行わない限り， Nm は本補強方法でブレースに期待する最大の 圧縮耐力となる。 $\mathrm{Nm}$ までの軸剛性の実験結果に対して (15) 式による 軸剛性の計算結果が適合するように, $\mathrm{k}$ の值を試行計算により求めた。 
表 1 ブレース試験体の一覧と実験耐力

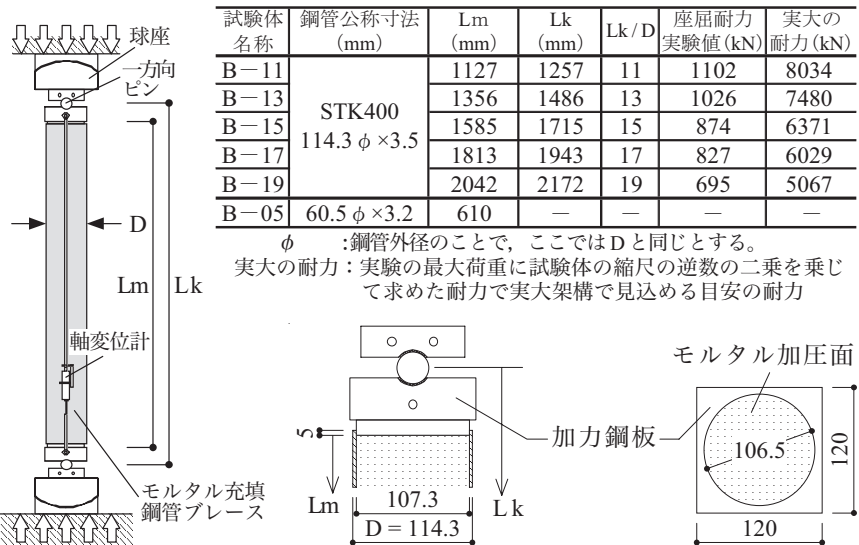

図 15 ブレース試験体の形状と寸法および加力状況

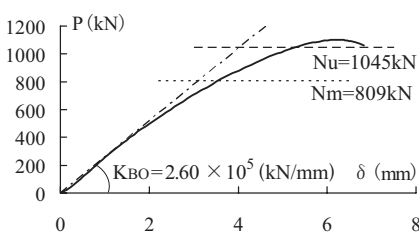

(a) $\mathrm{B}-11(\mathrm{Lk} / \mathrm{D}=11)$

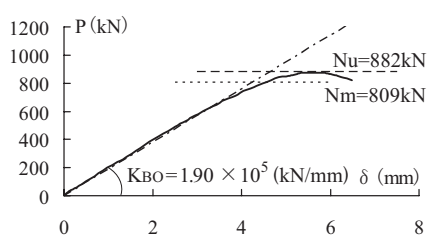

(c) $\mathrm{B}-15(\mathrm{Lk} / \mathrm{D}=15)$

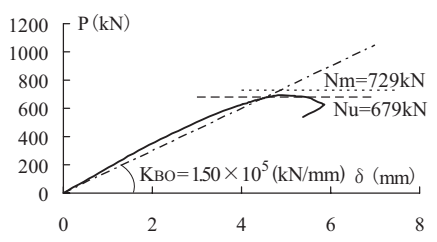

(e) $\mathrm{B}-19(\mathrm{Lk} / \mathrm{D}=19)$

図 16 ブレースの一軸厈縮実験の荷重一変形関係

その結果，kを $2.46 \%$ とした場合が実験結果を全般的に評価できると 判断した。図中には $\mathrm{K}$ во の計算值の関係を一点鎖線で示す。計算值 は実駼結果をほぼ推定している。 k を用いると，鋼管の有効面積 A s e は(16) 式で表される。(15) 式の $\gamma$ は(17) 式で表される。

$$
\begin{aligned}
\text { Ase } & =\left\{(1+\mathrm{k})^{2}-1\right\} \cdot \mathrm{Am} \fallingdotseq 0.05 \mathrm{Am} \\
\gamma & =\text { Ase } / \text { As }=0.05 \mathrm{Am} / \mathrm{As}
\end{aligned}
$$

ここに, $\mathrm{k}$ : 有効厚 e t s を鋼管内径の半径 $\mathrm{r}$ で除した比で $2.46 \%$

ブレースを接合する上下の梁では局所的な変形が生じる。この変形 成分を表すために便宜的に梁内に変形するコンクリートのブレースの 区間を設ける。ブレースの上下にそのコンクリートのブレースを直 列に連結した状態とする。またブレース内に制御部を設ける場合に は，ブレースの軸剛性を，制御部の区間とそれ以外の区間に分ける 必要がある。この場合にはブレースを制御部の区間とそれ以外の区 間に分けて直列に連結した状態として軸剛性を評価する。最終的に は，上下のコンクリートのブレースをまとめて，その軸剛性をKctb と し，制御部の区間の軸剛性を K by とし，制御部以外のブレースの軸 剛性を $\mathrm{K}$ во とすると, Кве は (18) 式で表される。この軸剛性を(1) 式
と (13) 式の K $\mathrm{K}_{\mathrm{Be}}$ に代入して層間変形を評価する。

$\mathrm{K}_{\mathrm{Be}}=1 /\left(1 / \mathrm{K}_{\mathrm{BO}}+1 / \mathrm{Kctb}+1 / \mathrm{Kby}\right)$

ここに, $\mathrm{K}_{\text {во }}$ （15) 式と (17) 式による。 $\mathrm{Kctb}=\mathrm{Ec} \cdot \mathrm{Am} /(2 \cdot \mathrm{d}+\mathrm{h})$, $(2 \cdot \mathrm{d}+\mathrm{h})$ : 上梁側の仮想ブレース長さと基礎梁側の仮想ブ レース長さの和である。 $2 \cdot \mathrm{d}$ は上梁側の仮想長さを意味し， $\mathrm{d}$ は鋼管内径である。この長さの根拠は 5.3.1 節で後述する。 $\mathrm{h}$ は基礎梁側の仮想長さを意味し，図24 (a) (b) または図 29 (b) 中に示すブレース軸上で基礎梁上端から基礎スラブ上端 までの距離である。この長さの根拠は 5.4.1 節で後述する。 $\mathrm{Kby}=\mathrm{Em} \cdot \mathrm{rAm} / \mathrm{rLm} ， \mathrm{Em}$ ：モルタルのヤング係数

$\mathrm{rAm}$ ：ブレース軸に対する制御部のモルタルの残存断面積 rLm：制御部のブレース軸方向の長さ

\section{2 ブレースの圧縮耐力 $\mathrm{Nu}$}

2 章で述べたように架構の形状・寸法・重量によっては梁が支圧 破壊する場合とブレースが座屈する場合が想定される。そのよう な場合には，そ机らの支圧耐力や座屈耐力ょりブレースの軸力を 小さくするようにブレースに制御部を設けて，そこを圧縮降伏さ せることが望ましい。以下に制御部を設けない場合と設ける場合 のブレースの圧縮耐力の評価方法を述べる。

\section{2 .1 制御部を設けない場合}

圧縮耐力 $\mathrm{Nu}$ は文献4) の指針 (以後, CFT 指針) の圧縮材の終局圧縮 耐力の設計式を用いる。図 16 中に同設計式による計算耐力を水平 の破線で示す。コンクリートの圧縮強度にモル夕ルの圧縮強度を 代入し，同指針に従って圧縮強度はシリンダー圧縮強度の $85 \%$ に 低減した。また強度特性は材料試験值を用いた。設計式は座屈長 さ Lk を断面せい D で除した比 Lk/D の大きさにより異なり，図 16 (a) は Lk/D が 4 から 12 の中柱の設計式を用い, それ以外では Lk/D が 12 以上の長柱の設計式を用いた。実験では座屈により耐力が決定し ている。計算耐力は座屈耐力を過大に評価することはなく CFT 指 針の設計式を準用できると判断できる。過大評価しないことは, 2.2 節で述べたようにブレースが座屈する以前に制御部を設けてブ レースを圧縮降伏させる設計では安全側となる。

図中の水平の点線は前述したモルタルだけの圧縮耐力 $\mathrm{Nm}$ である。 Lk/D が 19 になると座屈耐力が低下するため $\mathrm{Nu}$ が $\mathrm{Nm}$ より僅かに小さ くなる。しかし，架構に設けるブレースは材端がピン支持とならない ので $\mathrm{Lk}$ は材長 $\mathrm{L} よ り$ 短くなり，座屈耐力はさらに大きくなる。

鋼管の断面の形状比や材料の強度が同実験のものと同程度であれば, その座屈耐力は $\mathrm{Nm}$ 以上の耐力が確保されることになる。ただし，生 じる軸力が $\mathrm{Nm}$ より大きくなると，上下の材端では鋼管が斜めに切断 されるためモルタルに対する鋼管の拘束力が小さくなり，その部分の モルタルが圧縮破壊して接合面がずれはじめる5)。これを防ぐために は材端の局部補強5)を行うか, ブレースに制御部を設ける必要がある。

表 1 の右側に実験耐力に縮尺の逆数の二乗を乗じて求めた実大 架構で期待できる耐力を示す。設計の際に目安になる耐力である。

\section{2.2 制御部を設ける場合}

制御部の形状と寸法比は文献 1) の図 3 に準じるものとする。本文 図 4 (c) で示す降伏耐力 $\mathrm{Cy} 1$ はモル夕ルの残存断面積 $\mathrm{rAm}$ と圧縮強度 Fm の積で評価できる ${ }^{1)}$ 。降伏後に安定する耐力 Cy2 は文献 1) の実験を 基に $\mathrm{Cy}_{1}$ の 70\% とする。これらを式で表すと以下のようになる。 
表 2 上梁試験体の一覧と各種強度の実験值

\begin{tabular}{|c|c|c|c|c|c|c|c|c|c|c|c|c|c|c|c|c|c|}
\hline 試験体名 & 縮尺 & $\theta\left(^{\circ}\right)$ & $\mathrm{d} / \mathrm{B}$ & \begin{tabular}{|c|} 
充填深さ \\
$\mathrm{Sm}$ \\
\end{tabular} & \begin{tabular}{|c|} 
接合部 \\
形状 \\
\end{tabular} & $\begin{array}{c}\mathrm{F}_{\mathrm{C}} \\
\left(\mathrm{N} / \mathrm{mm}^{2}\right) \\
\end{array}$ & $\begin{array}{c}\mathrm{Fm} \\
\left(\mathrm{N} / \mathrm{mm}^{2}\right)\end{array}$ & 梁主筋 & あばら筋 & 壁筋 & $\begin{array}{c}\text { Pcr } \\
(\mathrm{kN})\end{array}$ & $\begin{array}{l}\text { Pmax } \\
(\mathrm{kN}) \\
\end{array}$ & Pcr / Pmax & $\begin{array}{c}\mathrm{Fb} \\
\left(\mathrm{N} / \mathrm{mm}^{2}\right)\end{array}$ & $\mathrm{c} \mathrm{Kb}$ & $\mathrm{m} \kappa \mathrm{b}$ & $\begin{array}{c}\text { 実大の } \\
\text { 耐力 }(\mathrm{kN})\end{array}$ \\
\hline No.1 & \multirow{6}{*}{$1 / 2.7$} & \multirow{4}{*}{60} & \multirow{4}{*}{$2 / 3$} & $\mathrm{D} / 8$ & \multirow{4}{*}{ 台形 } & 29.7 & 79.7 & \multirow{6}{*}{$\begin{array}{c}\text { 上端 } \\
4-\mathrm{D} 10 \\
\text { 下端 } \\
3-\mathrm{D} 10\end{array}$} & \multirow{6}{*}{$\begin{array}{r}\phi 3.5 @ 110 \\
\mathrm{pw}=0.12 \%\end{array}$} & \multirow{6}{*}{$\begin{array}{c}\phi 3.5 \\
@ 110 \\
\text { ダブル }\end{array}$} & 667 & \begin{tabular}{|l|}
723 \\
\end{tabular} & 0.923 & 88.0 & 2.96 & 1.10 & 5271 \\
\hline No. 2 & & & & $\mathrm{D} / 4$ & & 23.1 & 83.6 & & & & 不明 & 794 & 不明 & 96.6 & 4.18 & 1.16 & 5788 \\
\hline No. 3 & & & & $\mathrm{D} / 4$ & & 33.0 & 81.7 & & & & 不明 & 807 & 不明 & 98.2 & 2.98 & 1.20 & 5883 \\
\hline No.4 & & & & $3 \mathrm{D} / 8$ & & 27.7 & 83.6 & & & & 727 & 839 & 0.867 & 102.0 & 3.68 & 1.22 & 6116 \\
\hline No.5 & & 60 & 10 & $\mathrm{D} / 4$ & 体 & 23.3 & 79.2 & & & & 620 & 800 & 0.775 & 44.7 & 1.92 & 0.56 & 5832 \\
\hline No.6 & & 60 & 1.0 & $\mathrm{D} / 4$ & 体 & 33.5 & 86.3 & & & & 560 & 1090 & 0.514 & 60.9 & 1.82 & 0.71 & 7946 \\
\hline AT -60 & \multirow{5}{*}{$1 / 5$} & 60 & \multirow{5}{*}{0.6} & \multirow{5}{*}{$\mathrm{D} / 4$} & & \multirow{5}{*}{37.3} & \multirow{5}{*}{74.2} & \multirow{5}{*}{$6-\mathrm{D} 6$} & \multirow{5}{*}{$\begin{array}{c}\phi 2.5 @ 40 \\
\mathrm{pw}=0.27 \%\end{array}$} & \multirow{5}{*}{$\begin{array}{l}\text { D6@60 } \\
\text { シングル }\end{array}$} & 不明 & 242 & 不明 & 105.3 & 2.82 & 1.42 & 6050 \\
\hline $\mathrm{AT}-70$ & & 70 & & & & & & & & & 200 & 237 & 0.844 & 103.1 & 2.76 & 1.45 & 5925 \\
\hline $\mathrm{AR}-90$ & & 90 & & & & & & & & & 194 & 231 & 0.840 & 100.5 & 2.69 & 1.35 & 5775 \\
\hline $\mathrm{AR}-60$ & & 60 & & & 直方体 & & & & & & 不明 & 242 & 不明 & 105.3 & 2.82 & 1.42 & 6050 \\
\hline $\mathrm{AR}-70$ & & 70 & & & & & & & & & 200 & 247 & 0.810 & 107.5 & 2.88 & 1.39 & 6175 \\
\hline
\end{tabular}

$\mathrm{Fc}$ : コンクリートのシリンダー厈縮強度, $\mathrm{Fm}:$ モタルのシリンダー圧縮強度, Pcr：初期ひび割れ発生荷重, Pmax：最大耐力, $\mathrm{Fb}$ ：支圧強度 実大の耐力：実験の最大荷重に試験体の縮尺の逆数の二乗を乗じて求めた耐力で実大架構で見込める目安の耐力

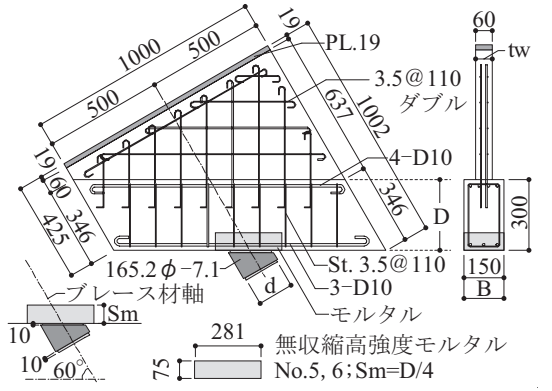

図 17 上梁試験体の形状・配筋・寸法

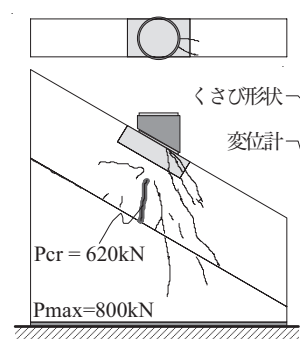

(a) No.5

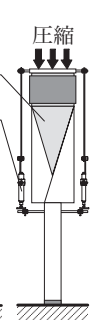

(b)

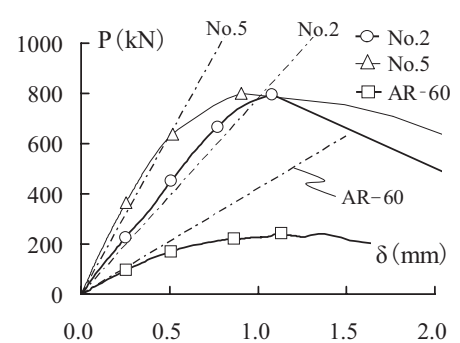

図 19 圧縮荷重一変形関係

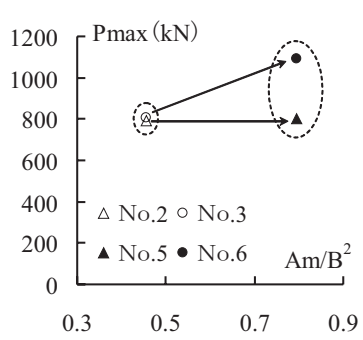

図20 $\mathrm{Pmax}-\mathrm{Am} / \mathrm{B}^{2}$ 関係

図 18 最終破壊状況と破壊形式

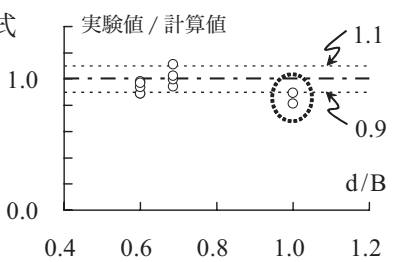

( a ) 極限解析による計算

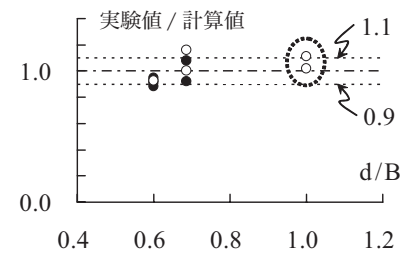

(b) (20) 式による計算

\section{3.1 既報 5) 7) の上梁の支圧実験概要と剛性}

図 22 に示す 2 階の梁の網掛けの部分をモデル化した試験体の支圧 実験を行っている。表 2 に一連の試験体の一覧を示す。図 17 に試験 体の一例を示す。試験体は, 縮尺を実大の $1 / 2.7$ または $1 / 5$ とし, ブレー スの設置角度 $\theta\left(60^{\circ} \sim 90^{\circ}\right)$, 梁幅 $\mathrm{B}$ に対するブレース鋼管内径 $\mathrm{d}$ の 比 $\mathrm{d} / \mathrm{B}$, モル夕ルを充填する欠損部のモル夕ル深さ $\mathrm{Sm}$ と形状, 既存コ ンクリートの圧縮強度 $\mathrm{F} \mathrm{c}$ などを変数としている。試験体数は 11 体で ある。ブレースの両端では鋼管は縁切りされている。図 18 に最終 破壊状況の例と破壊形式を示す。同図に示す状態で試験体を耐圧試 験機に設置し，一軸圧縮加力を行っている。

図中には初期ひび割れを太線で示し, ひび割れが発生した荷重 P c r と最大荷重 $\mathrm{P}$ max を数值で示す。破壊経過は, 約 $0.5 \sim 0.9 \mathrm{P} \max$ で梁側 面のコンクリート部分にひび割れが発生し, 最大荷重直前で梁上面 にひび割れが発生し, 最大荷重以降, 鋼管が縁切りされた区間のモル タル部分が梁内にめり込み支圧破壊した。破壊形式は全試験体とも 図 18 (b) に示すように円錐状の楔が形成され非対称にすべり破壊した。

図 19 に圧縮荷重一変形関係の例を示す。最大荷重の直前まではほぼ 直線関係になり，支圧破壊するため最大荷重後は耐力低下が生じる。 梁部分ではめり込み変形が生じる。半無限弾性体において面圧縮加 力を行う場合, 加力面から加力面幅の 2 倍程度の距離の範囲に主に ひずみが生じ，加力方向のめり込み変位は同方向のひずみを積分し たものとなる。上梁試験体では壁と一体になった梁を大まかに無限 板と見なせ，ブレースの接合断面を加力面と見なせる。このことを 考慮して 5.1 節で述べたように簡略的に梁内に仮想のコンクリートの ブレースを設けて最大荷重前のめり込み変形を表すことにした。全 上梁試験体の最大荷重以前の荷重 - 変形関係の実験結果を全般的によ く評価できるブレースの仮想長さを試行計算により求めた。その結果,

\section{図 21 計算值に対する実験值の比}

モルタル断面の直径 $\mathrm{d}$ の 2 倍が妥当であると判断した注2)。これ を用いて計算した荷重一変形関係を図 19 に一点鎖線で示す。その計 算による荷重一変形関係は最大荷重以前までの荷重一変形関係の実 験結果を概ね近似している。

表 2 の右側に実験值を示す。F $\mathrm{F}$ は最大荷重をモルタルの断面積 $\mathrm{Am}$ で除した支圧強度である。 $\mathrm{c} K \mathrm{~b}$ は $\mathrm{Fb}$ をコンクリートの圧縮強度 $\mathrm{Fc}$ で除した強度比, $\mathrm{m} K \mathrm{~b}$ は $\mathrm{Fb}$ をモルタルの圧縮強度 $\mathrm{Fm}$ で除した強度 比である。同表の No.2, No.3 はそれぞれNo.5, No.6 と材料強度がほぼ 同じで, Sm も同じである。これらについて図20 に最大荷重P $\max と モ$ ルタルの断面の面積比 $\mathrm{Am} / \mathrm{B}^{2}$ の関係を示す。 $\mathrm{B}^{2}$ は梁幅 $\mathrm{B}$ を一辺とす る正方形の面積である。 d / B を $2 / 3$ から 1.0 にするとモル夕ル面積 Am は約 2.3 倍になるが, 耐力は 1.0 または 1.35 倍にしか増大しない。こ れは材料の使用量の観点から効率がよくないことを意味する。表 2 の右端に表 1 と同様に計算した実大架構で期待できる耐力を示す。

\section{3.2 上梁の支圧耐力 $\mathrm{t} \mathrm{Pb}$ の計算と設計式}

塩屋ら ${ }^{6)}$ は極限解析により支圧耐力を評価する基礎式を誘導して いる。図 21 ( a ) にその計算值に対する実験值の比を示す。横軸は d/B としている。d/B が 1.0 で点線で囲んだ計算值は実験值を過大評価し ている。これは, 同解析モデル6)においてはブレースにより形成され る円錐状のくさびの周辺に拘束力を期待するが， d/B が1.0 になると, その拘束力が減少することが原因と考元られる。このことも考慮して 文献 6) の基礎式から近似式の（20) 式を誘導した。同式は $\theta$ を $60^{\circ}$, $\mathrm{Sm} / \mathrm{D}$ を 0.25 と範囲を限定して簡略化した。右辺の $\phi$ が前述の拘束力 の低減を考慮する係数である。図21 (b) に(20) 式による計算結果を示す。 
表 3 基礎梁試験体の一覧と各種強度の実験值

\begin{tabular}{|c|c|c|c|c|c|c|c|c|c|c|c|c|c|c|c|c|}
\hline 試験体名 & 縮尺 & $\theta\left(^{(\circ)}\right.$ & $\mathrm{d} / \mathrm{B}$ & \begin{tabular}{|c|}
$\begin{array}{c}\text { 充填深さ } \\
\text { Sm }\end{array}$ \\
\end{tabular} & $\begin{array}{c}\text { 接合部 } \\
\text { 形状 } \\
\end{array}$ & $\begin{array}{c}F_{C} \\
\left(\mathrm{~N} / \mathrm{mm}^{2}\right) \\
\end{array}$ & $\begin{array}{c}\mathrm{Fm} \\
\left(\mathrm{N} / \mathrm{mm}^{2}\right) \\
\end{array}$ & $\begin{array}{c}\text { 基礎梁の曲げ } \\
\text { ひび割れの有無 } \\
\end{array}$ & $\begin{array}{c}\text { 基礎スラブの厚さ } \\
(\mathrm{mm}) \\
\end{array}$ & $\begin{array}{l}\text { Pcr } \\
(\mathrm{kN})\end{array}$ & $\begin{array}{l}\operatorname{Pmax} \\
(\mathrm{kN}) \\
\end{array}$ & Pcr / Pmax & $\begin{array}{c}\mathrm{Fb} \\
\left(\mathrm{N} / \mathrm{mm}^{2}\right)\end{array}$ & $\mathrm{c} \kappa \mathrm{b}$ & $\mathrm{m} \kappa \mathrm{b}$ & $\begin{array}{c}\text { 実大の } \\
\text { 耐力 }(\mathrm{kN})\end{array}$ \\
\hline $\mathrm{B}-1 / 8$ & $1 / 5$ & 60 & 0.6 & $\mathrm{D} / 8$ & 直方体 & 36.9 & 74.4 & あり & 200 & 136 & 232 & 0.586 & 100.9 & 2.73 & 1.36 & 5800 \\
\hline $\mathrm{B}-1 / 4$ & & & & $\mathrm{D} / 4$ & & 36.9 & 14.4 & あり & 200 & 190 & 243 & 0.782 & 105.7 & 2.86 & 1.42 & 6075 \\
\hline $\mathrm{C} 1$ & \multirow{4}{*}{$1 / 5$} & \multirow{4}{*}{60} & 0.6 & \multirow{4}{*}{$\mathrm{D} / 4$} & \multirow{4}{*}{ 直方体 } & 329 & 704 & \multirow{4}{*}{$\begin{array}{l}\text { あり } \\
\text { なし } \\
\text { あり } \\
\text { なし }\end{array}$} & \multirow{3}{*}{200} & 260 & 286 & 不明 & 124.0 & 3.77 & 1.76 & 7138 \\
\hline C2 & & & 0.0 & & & 32.9 & 70.4 & & & 250 & 265 & 0.943 & 115.4 & 3.51 & 1.64 & 6630 \\
\hline $\mathrm{C} 3$ & & & 100 & & & 207 & 835 & & & 315 & 445 & 0.707 & 70.0 & 3.38 & 0.84 & 11133 \\
\hline $\mathrm{C} 4$ & & & 1.0 & & & 20.1 & 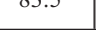 & & 100 & 260 & 321 & 0.810 & 50.4 & 2.43 & 0.60 & 8020 \\
\hline
\end{tabular}

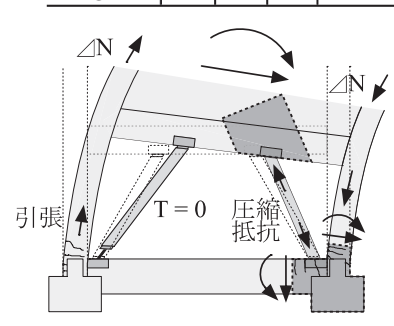

図22 上梁と基礎梁まわりの内力

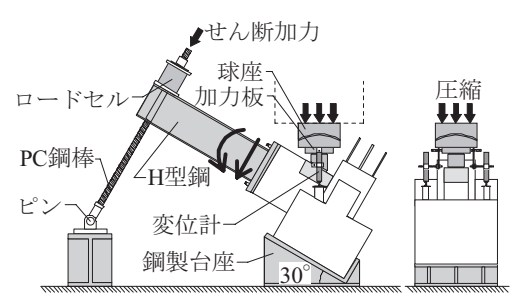

図23 加力状況と変形の測定状況

同図の計算では $(20)$ 式の右辺の $\gamma$ を 1.0 としている。○は適用範 囲のデータで, ○は $\theta$ が $90^{\circ} や \mathrm{Sm} / \mathrm{D}$ が $1 / 8,3 / 8$ など適用範囲外の データである。 $\theta$ や Sm / D が前述の範囲外でも (20) 式は実験值を ほぼ推定している。設計式としては, 実験の下限值を安全側で評価す るために (20) 式の右辺の $\gamma$ を 0.9 とする式を提案する。

$$
\mathrm{t} \mathrm{Pb}=\kappa \cdot \mathrm{Fm} \cdot \mathrm{Am} \cdot \phi \cdot \gamma
$$

$$
\text { ここに }, \kappa=\mathrm{a} \cdot(\mathrm{D} / \mathrm{d}-1.5)+\mathrm{b}
$$

$\mathrm{a}=\left(0.62 \cdot \mathrm{Fc}_{\mathrm{c}} / \mathrm{Fm}_{\mathrm{m}}-0.021\right) \cdot\left(\mathrm{t}_{\mathrm{w}} / \mathrm{d}\right)+0.22$

$\mathrm{b}=(1.28 \cdot \mathrm{Fc} / \mathrm{Fm}-0.33) \cdot\left(\mathrm{tw}_{\mathrm{w}} / \mathrm{d}\right)^{0.26}$

$\phi=1.3-0.5 \cdot(\mathrm{d} / \mathrm{B})$

$\gamma:$ 実験值の評価では 1.0 , 設計では 0.9

$\mathrm{Fm}$ : モルタルのシリンダー圧縮強度

F c : コンクリートのシリンダー圧縮強度

$\mathrm{Am}$ : ブレース内のモルタル軸断面積, D: 梁せい, B: 梁幅 $\mathrm{d}$ : 鋼管内径, tw: 壁厚, (20) 式の適用範囲を以下に示す。 $0.6 \leqq \mathrm{~d} / \mathrm{B} \leqq 1.0,15 \leqq \mathrm{Fc}\left(\mathrm{N} / \mathrm{mm}^{2}\right) \leqq 35,70 \leqq \mathrm{Fm}\left(\mathrm{N} / \mathrm{mm}^{2}\right) \leqq 90$

\section{4 基礎梁の剛性と支圧耐力}

\section{4. 1 既報7) 111) の基礎梁の支圧実験概要と剛性}

基礎のまわりには図 22 に示すような内力が生じる。左側の引張柱で は引張ひび割れが発生し，右側の基礎梁の上端側では曲げひび割れが 発生する。このような状況の基礎梁について支圧実験を行っている。

表 3 に一連の試験体の一覧を示す。図 24 に試験体の形状・配筋・寸 法を示す。試験体は縮尺を実大の $1 / 5$ とし，梁幅 B に対するブレース鋼 管内径 $\mathrm{d}$ の比 $\mathrm{d} / \mathrm{B}$, モル夕ルを充填する欠損部の形状は直方体でモル夕 ル深さ $\mathrm{Sm}$, 既存コンクリートの圧縮強度 $\mathrm{Fc}$, 基濋梁の曲げひび割れの有無, 基礎スラブの厚さを変数としている。ブレース設置角度 $\theta$ は $60^{\circ}$ の 1 種 類である。試験体数は 6 体である。

ブレースの両端には鋼管の縁切り区間 $(5 \mathrm{~mm})$ を設けている。加力は まず柱に引張加力を行い, 柱に水平ひび割れを発生させた。この時の 引張力は全引張降伏耐力の $74 \%$ とした。つぎに図 23 に示すように試 験体を $30^{\circ}$ 傾けた状態で耐圧試験機に設置して圧縮加力を行った。 圧縮加力の途中で基礎梁に曲げせん断加力を行い基礎梁上端側に曲 げひび割れを発生させている。この時，フーチングと基礎梁の境界面 の曲げモーメントは基礎梁の降伏モーメントとした。試験体 C2, C4 で はその曲げせん断加力は行っていない。

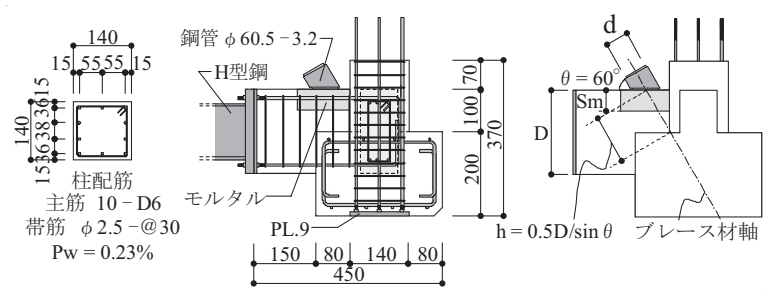

(a) $\mathrm{B}-1 / 8, \mathrm{~B}-1 / 4, \mathrm{C} 1, \mathrm{C} 2, \mathrm{C} 3$

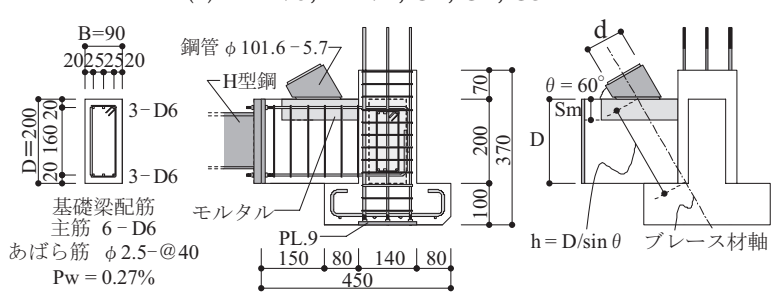

(b) $\mathrm{C} 4$

図 24 基礎梁試験体の形状・配筋・寸法

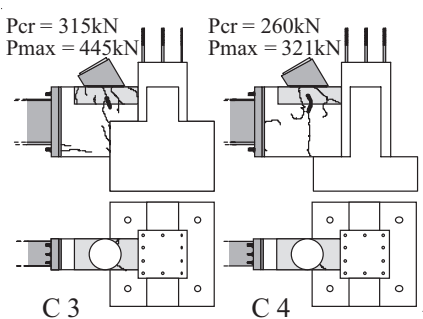

図 25 最終破壊状況

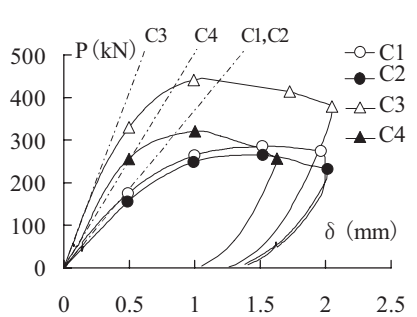

図 26 圧縮荷重一変形関係
図25 に最終破壞状況の例を示す。初期ひび割れを太線で示し，その ひび割れが発生した荷重 P c r と最大荷重P max を数值で示す。圧縮加力 では, モルタル充填部側面にブレース軸の延長線にひび割れが生じ， モルタル充填部上面にひび割れが生じた。その後, 最大荷重に達して 支圧破壊した。支圧破壊の範囲は基礎梁の範囲内に収まり，フーチン グや柱にひび割れは進展しなかった。表 3 に表 2 と同様に実験值を 示す。図 26 に圧縮荷重一変形関係の例を示す。 $\mathrm{C} 1$ と C 2 ではあまり 差はなく, 梁に曲げモーメントを加力してひび割れを生じさせた C 1 の方が耐力は大きくなっている。C3 と C4では, 梁せいを大きくして 基礎スラブ厚を小さくした $\mathrm{C} 4$ の最大荷重が小さくなっている。これ は破壊が梁だけに留まったことから梁せいが大きくなったことが要 因と考えられる。基礎梁側のめり込み変形の評価は，その部分が基 礎スラブと柱および基礎梁からなり，上梁の形状と異なるため，ブ レース軸上で基礎梁上端から基礎スラブ上端までの距離を，5.1 節で 述べたコンクリートのブレースの仮想区間 h とすることにした。こ れを用いて計算した荷重一変形関係を図 26 中に一点鎖線で示す。計 算の荷重一変形関係は最大荷重以前までを概ね近似している。

5. 4.2 基礎梁の支圧耐力 $\mathrm{f} \mathrm{Pb}$ の計算と設計式

基礎梁についても上梁と同様に，極限解析に基づき支圧耐力の計算 を行った。図 27 に計算值に対する実験值の比を示す。৩のデー夕を 


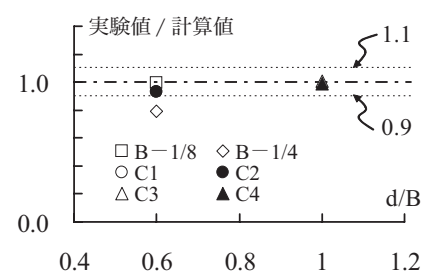

図 27 計算值に対する実験值の比
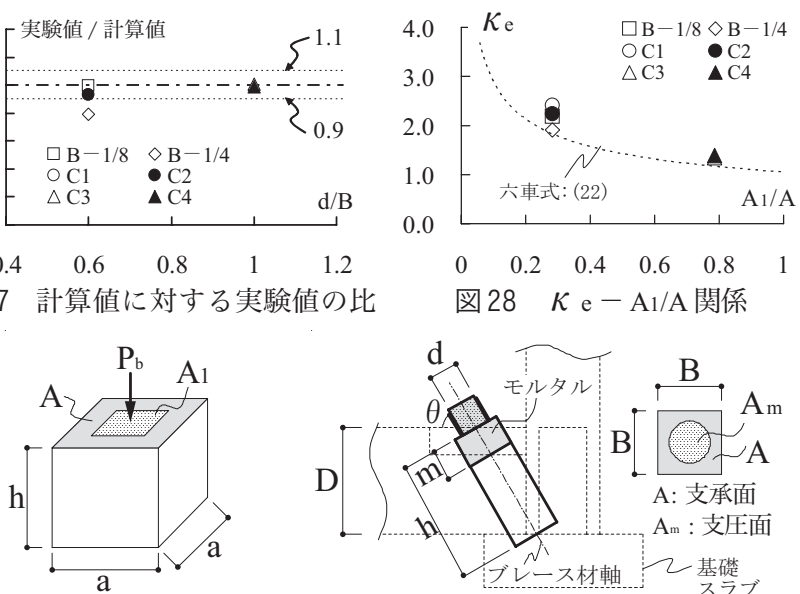

(a ) 既往の直方体モデル

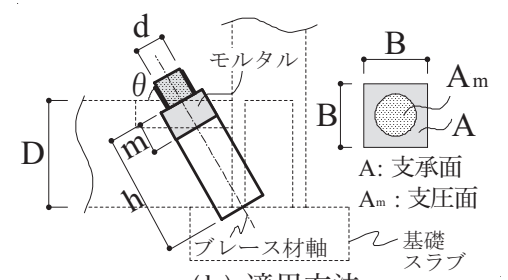

(b) 適用方法

図 29 既往の支圧実験の加力状況と (22) 式の適用方法

除くと, 計算值は実験值を精度よく推定している。しかし, 基礎梁の 解析モデルは複雑で, その基礎式を実用式として簡略化するのは困難 と判断した。そこで, 六車ら ${ }^{8)}$ の支圧耐力の実験式の (22) 式を基礎梁 の実験データに適合するように適用方法を修正した。

既往の研究 ${ }^{8)}$ よると, 図 29 (a) に示す直方体の高さ比 $\mathrm{h} / \mathrm{a}$ が 1.0 より 小さくなると同じ支圧面積であっても支圧耐力は増大し，1.0 より大 きくなるとあまり変化しない。その増加耐力を定量的に評価するこ とは難しく，また支圧耐力を安全側で評価する観点から，ここでは その増加耐力は見込まないことにする。基礎梁側を図 29 (b) のように モデル化し, 支承面積 $\mathrm{A}$ を梁幅 $\mathrm{B}$ を一辺とする正方形の面積 $\mathrm{B} \times \mathrm{B}$ と し, 支圧面積 $\mathrm{A} 1$ をブレースのモルタルの軸断面積 $\mathrm{Am}$ とする。モデル での直方体の高さ $\mathrm{h}$ は, 図 29 (b) の h とする。この区間においては高強 度のモルタルと既存コンクリートが存在する。(21) 式ではこの区間の 圧縮強度が必要となる。支圧破壊は支圧面の直下に楔が形成される形 ですべり破壊と, その他の領域における引張破壊が複合する。図29(b) のモデルで単に一軸圧縮状態を想定し, 圧縮強度の小さい既存コンク リートの圧縮強度を用いて圧縮耐力を計算すると実験結果を説明でき

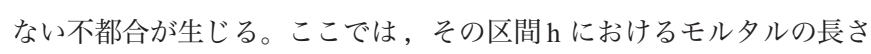
$\mathrm{m}$ とコンクリートの長さ $(\mathrm{h}-\mathrm{m})$ の占める割合によって，モルタルの圧 縮強度 $\mathrm{Fm}$ とコンクリートの圧縮強度 $\mathrm{F} \mathrm{c}$ に重みを付けた見掛けの圧縮 強度 $\mathrm{Fe}$ を圧縮強度として(23) 式を用いることにした。Fm と Fc はシリ ンダー圧縮強度である。 $\mathrm{Fe}$ で支圧強度 $\mathrm{Fb}$ を除した比 $\mathrm{Fb} / \mathrm{Fe}$ を支圧強度 比 $\kappa \mathrm{e}$ とし, 実験デー夕を整理して支圧面積比 $\mathrm{A} 1 / \mathrm{A}$ との関係を観たもの が図28である。図中には(22) 式の曲線も点線で示す。(22) 式は全試験 体とも実験值を安全側で評価している。基礎梁の支圧耐力式として 表したものが(21) 式である。これを設計式として提案する。ただし, 同式の $\mathrm{Fe}$ は大胆な仮定に基づいている。これについては今後, 追加 実験や詳細な解析による検証が必要である。現時点での (23) 式の適用 範囲は，検証に用いた試験体に基づくと，既存コンクリートの圧縮強 度が $20 \mathrm{~N} / \mathrm{mm}^{2} \sim 37 \mathrm{~N} / \mathrm{mm}^{2}$ となる。このほか, 基礎のスラブ厚が小さ い場合にはスラブの耐力の検討が必要になる。

$$
\begin{aligned}
& \mathrm{fPb}=\kappa_{\mathrm{e}} \cdot \mathrm{Fe} \cdot \mathrm{Am} \\
& \kappa_{\mathrm{e}}=1.05 \cdot\left(\mathrm{A} / \mathrm{A}_{1}\right) 1 / 2.28 \\
& \mathrm{Fe}=\mathrm{Fc}+\left(\mathrm{Fm}-\mathrm{Fc}_{\mathrm{c}}\right) \cdot \mathrm{m} / \mathrm{h}
\end{aligned}
$$

$\mathrm{Fm}$ : モルタルのシリンダー圧縮強度

F c : コンクリートのシリンダー圧縮強度

\section{6. まとめ}

補強するピロティ層における，ブレースと柱の負担水平力と層間 変形角の関係の特徵を弾塑性骨組解析で明らかにして, これに基づ いて層せん断力一層間変形角関係の評価方法を提案した。提案した 評価方法は, 一般の耐震診断の手計算で評価できるように整備した。

評価方法による計算結果は, 全体曲げ降伏する場合の実験の包絡 線を精度よく推定し，ブレースの設置角度を変化させた場合の解析結 果も精度よく推定できた。また評価方法はブレースの接合部が支圧 破壊する場合やブレースを圧縮降伏させる場合にも適用できるよう に構成しており，これらの場合についても実験の包絡線を精度よく 評価できた。さらに補強設計で重要となる, ブレースの剛性と耐力, ブレースと上下梁の接合部の剛性と支圧耐力の評価方法も示し，ま た実験值に基づいて実大架構で見込める耐力も示した。

本評価方法で示した基礎梁の支圧耐力式は実験結果を根拠に誘導 しているため, 基礎梁の既存コンクリートの圧縮強度が， $20 \mathrm{~N} / \mathrm{mm}^{2}$ 〜 $37 \mathrm{~N} / \mathrm{mm}^{2}$ の範囲から外れる場合にはその耐力式は現時点では適用で きない。その範囲から外れる場合には実験や解析による妥当な根拠 を持って支圧耐力を設定する必要がある。

注

注 1) hp は地震時の水平力分布の重心高さである。無補強のピロティ架構の場合, 2 階以上の水平力の分布は等分布に近く，1階にも耐震壁が設けられる連層 耐震壁の場合，逆三角形分布に近くなる。本補強を用いる場合，それらの間 の分布になる。耐震性能を評価する場合には補強後のピロティ層の層剛性 を用いた $\mathrm{Ai}$ 分布に基づく水平力の分布を用いる方法 ${ }^{9)}$ が考えられる。

注2) 図 18 では壁部分までひび割れが生じているが, それは最終破壊状況で最大 荷重以前の剛性を評価する仮想長さと直接，関係するものではない。

参考文献

1）塩屋晋一, 大川光雄, 幸加木宏亮: 圧縮ブレースを用いる既存 $\mathrm{RC}$ 造ピロ ティ架構の耐震補強に関する実験的研究, 日本建築学会構造系論文集, 第 621 号, pp.127-134, 2007.11

2）岡元夕弥, 塩屋晋一, 大川光雄 : 圧縮抵抗型ブレースを用いて耐震補強さ れる RC ピロティ架構の剛性・強度・変形の評価, 日本コンクリート工学 年次論文集 , vol.29, No.3,pp.1171-1176, 2007.7

3) 増田祐一郎, 塩屋晋一, 木宮玄喜, 河野圭悟 : 圧縮抵抗型ブレースを用い る RC 造ピロティ架構の耐震補強におけるブレースの座屈耐力と補強効果, 日本コンクリート工学年次論文集 , vol.27, pp.1111-1116, 2005.6

4) 日本建築学会 : コンクリート充填鋼管構造設計施工指針, pp.34-38, 1997

5）塩屋晋一，上荒磯崇ほか：圧縮抵抗型ブレースを用いる RC 造ピロティ架構 の耐震補強, 日本コンクリー工学年次論文集, vol.25,pp.1561-1566, 2003.7

6）幸加木宏亮・塩屋晋一・河野圭悟・原田喜実：压縮抵抗型ブレースを用 いる既存 RC 造ピロティ架構の耐震補強における既存梁部分の支圧耐力, 日本コンクリート工学年次論文集, vol.27, pp.1105-1110, 2005.6

7）大川光雄, 塩屋晋一, 幸加木宏亮, 江頭裕介 : 圧縮抵抗型ブレースを用 いる既存 RC ピロティ架構の耐震補強における梁の支圧実験, コンク リート工学年次論文集, vol.28, No.2, pp.1141-1146, 2006.7

8）日本建築学会 : 鉄筋コンクリート終局度設計に関する資料, pp.70, 71, 90, 97, 1987

9）日本建築防災協会 : 2001 年改訂版既存鉄筋コンクリート造建築物の耐震診 断基準, pp.78, 204, 2001

10) 塩屋晋一, 當房和博 : 腰壁・垂れ壁が中心接合される RC 柱のせん断耐力, 日本建築学会構造系論文集, 第 619,pp. 149-156, 2007.9

11）岡元夕弥, 塩屋晋一, 大川光雄 : 圧縮ブレースを用いる既存 $\mathrm{RC}$ 造ピロティ 架構の耐震補強に関する研究 (梁接合部の支圧耐力の設計式の検討) , 日本 建築学会九州支部研究報告, 第 47 号, pp.433-436, 2008.3

（2008年 1 月10日原稿受理，2008年 6 月24日採用決定）

ここに, $\mathrm{A}=\mathrm{B} \times \mathrm{B}, \mathrm{A} 1=\mathrm{Am}$, これらと $\mathrm{m}, \mathrm{h}$ は図 29 を参照のこと。 